\title{
Bronchial hyperreactivity induced by tropomyosins from cockroach and shrimp: a mouse model to study in vivo cross-reactivity
}

\author{
Thalita Martins, Marina Dias, Rafael Prado, Thamires Milani, Adriana S Moreno, Luana Maia, Vânia Bonato, \\ Simone Ramos, Marcos Borges, L Karla Arruda
}

From 3rd WAO International Scientific Conference (WISC) 2014

Rio de Janeiro, Brazil. 6-9 December 2014

\section{Background}

In vivo cross-reactivity among tropomyosins, major panallergens among invertebrates, is not established. Our aim was to investigate the effects of purified tropomyosins from cockroach (recombinant Per a 7) and shrimp (natural Lit $v$ 1) on airway inflammation and hyperresponsiveness in a mouse model of asthma.

\section{Methods}

Balb/c mice, 4 to 6 weeks-old, were sensitized twice with $50 \mu \mathrm{g}$ of rPer a 7 or nLit v 1 intraperitoneally with $1 \mathrm{mg}$ alum, and challenged with $50 \mu \mathrm{g}$ of rPer a 7 or nLit v 1 intranasally for three days. A group was sensitized with rPer a 7 and challenged with nLit $\mathrm{v} 1$ under same conditions. Controls received saline on same days. Twenty-four hours after the last challenge, mice were ventilated with FlexiVent ${ }^{\circledR}$, and in vivo bronchial hyperresponsiveness was evaluated with increased doses of inhaled methacholine $(6.25,12.5$, 25 and $50 \mathrm{mg} / \mathrm{ml}$ ). After ventilation, bronchoalveolar lavage fluid (BALF) was collected and cell counts were performed.

\section{Results}

Sensitization and challenge of mice with rPer a 7 or nLit $\mathrm{v} 1$ resulted in increase in bronchial hyperresponsiveness, given by increase in total and tissue resistance and elastance. Total cells in BALF increased in rPer a 7 $\left(1 \times 10^{5}\right.$ vs $\left.3 \times 10^{5}, \mathrm{p}<0.01\right)$ and nLit v $1\left(1 \times 10^{5}\right.$ vs $1 \times 10^{6}$, $\mathrm{p}<0.001)$ groups, as compared to controls. There was increase in macrophages for rPer a $7\left(5 \times 10^{4}\right.$ vs $1 \times 10^{5}$, $\mathrm{p}<0.001)$ and nLit v $1\left(5 \times 10^{4}\right.$ vs $\left.3 \times 10^{5}, \mathrm{p}<0.001\right)$ and eosinophils for rPer a $7\left(2 \times 10^{3}\right.$ vs $\left.1.4 \times 10^{5}, \mathrm{p}<0.001\right)$ and nLit v $1\left(2 \times 10^{3}\right.$ vs $\left.9.1 \times 10^{5}, \mathrm{p}<0.001\right)$. Mice immunized

School of Medicine of Ribeirao Preto - University of Sao Paulo, Brazil with $\mathrm{rPer}$ a 7 and challenged with nLit $\mathrm{v} 1$ showed no changes in bronchial hyperresponsiveness or eosinophils on BALF as compared to controls $\left(2 \times 10^{3}\right.$ vs $\left.6 \times 10^{3}\right)$. However, there was an increase in neutrophils in this group as compared to controls $\left(5 \times 10^{4}\right.$ vs $\left.1 \times 10^{5}, \mathrm{p}<0.01\right)$.

\section{Conclusions}

Experimental asthma induced by purified tropomyosins from cockroach and shrimp mimicked the main characteristics of human asthma. Despite the high degree of sequence identity and IgE immunologic cross-reactivity, our data suggested that in vivo cross-reactivity of these tropomyosins is unlikely.

Published: 8 April 2015

doi:10.1186/1939-4551-8-S1-A264

Cite this article as: Martins et al:: Bronchial hyperreactivity induced by tropomyosins from cockroach and shrimp: a mouse model to study in vivo cross-reactivity. World Allergy Organization Journal 2015 8(Suppl 1):A264.

Submit your next manuscript to BioMed Central and take full advantage of:

- Convenient online submission

- Thorough peer review

- No space constraints or color figure charges

- Immediate publication on acceptance

- Inclusion in PubMed, CAS, Scopus and Google Scholar

- Research which is freely available for redistribution 